Original Research

Cardiorespiratory fitness, Body composition and Bone markers of athletes

\title{
The Relationship Between Maximal Oxygen Intake, Body Fat and Bone Marker Measurements in Different Sports Branches
}

\author{
Serap Demir ${ }^{1}$, Armağan A. Yürük ${ }^{1}$ \\ ${ }^{1}$ Hacettepe University, Faculty of Health Sciences, Department of Nutrition and Dietetics
}

\begin{abstract}
Objectives: The purpose of our study is to evaluate the interaction between maximal oxygen intake, body composition and some bone marker measurements in Turkish elite players.

Methods: A total of 51 Turkish players of Turkish Super League from following disciplines were included in the study: football (25 players), basketball (12 players) and volleyball (14 players). Maximal oxygen intake as a cardiorespiratory fitness measurement and some anthropometric measurements such as body weight, fat mass, fat free mass were measured. We analyzed the serum samples for total serum $25(\mathrm{OH}) \mathrm{D}$ and calcium levels. The data of individuals were categorized as indoor sports (volleyball and basketball) and outdoor sports (football); also according to the branches.

Results: In this study, it was found that, fat mass $(\mathrm{p}=.019)$ and fat free mass $(\mathrm{p}=.000)$ were significantly higher for indoor sports athletes. On the contrary, $\mathrm{VO}_{2}$ max intake $(\mathrm{p}=.001)$ and serum vitamin $25(\mathrm{OH}) \mathrm{D}(\mathrm{p}=.000)$ levels were significantly lower in indoor athletes. For all participants, only $51.0 \%$ subjects had sufficient serum vitamin 25(OH)D. It was found that vitamin $\mathrm{D}$ levels was inversely related with body weight (spearman $\mathrm{r}=-0.41$, $\mathrm{p}=.003$ ), fat free mass (spearman $\mathrm{r}:-0.51, \mathrm{p}=.000$ ) and basal metabolic rate (spearman $\mathrm{r}:-0.35, \mathrm{p}=.012$ ). We found no significant correlation between total calcium levels and any of the other parameters.

Conclusion: In Turkish athletes, better cardiorespiratory fitness and lower percent of body fat were associated with higher serum $25(\mathrm{OH}) \mathrm{D}$ level. All these data were independent of serum total calcium level.
\end{abstract}

Keywords: serum 25(OH)D, maximal oxygen intake, body fat percentage

Corresponding Author: Serap Demir, Hacettepe University, Faculty of Health Sciences, Department of Nutrition and Dietetics, +90 312305 1094, serap.demir@ hacettepe.edu.tr 


\section{Introduction}

The skeletal system is the most important part of overall health for the athletic population. Up to 18 years, the bone mass reaches to $90 \%$ of its maximal level; declines after menopause in women and is largely influenced by genetic factors (Baile, McKay, Mirwald, Crocker, Faulkner, 1999). Besides genetics, other modifiable factors affect bone health, such as exercise, nutrition, smoking, medications and calcium intake (Whiting, Vatanparast, Baxter-Jones, Faulkner, Mirwald, Bailey, 2004). Physical activity plays a key role in bone mineralization till adulthood. Adequate formation of bone mass may reduce fracture risk by $50 \%$ to $80 \%$ (Nordstrom, Karlsson, Nyquist, Olsson, Nordstrom, 2005). Other factors that may contribute maximum peak bone mass are the percentage of body fat, serum total calcium, serum 25-hydroxyvitamin D (25(OH)D) and parathyroid hormone (PTH) levels (Heller, Thomas, Hollis, Larson-Meyer, 2015). PTH functions to maintain optimum blood calcium level. PTH and serum calcium levels regulate the formation of $1,25(\mathrm{OH})_{2} \mathrm{D}$ from $25(\mathrm{OH}) \mathrm{D}$. The 25(OH)D is needed to enhance absorption of calcium and phosphorus from the intestine. That is why, serum 25(OH)D level is an important factor for optimizing bone mass (Sohl, Jongh, Heymans, Schoor, Lips, 2015). It is shown that the levels of serum PTH is inversely associated with the serum level of 25(OH)D (Gutierrez, Farwell, Kermah, Taylor, 2011).

It is reported that nearly one billion people have vitamin D-deficiency or insufficiency (Holick et al. 2012). Also there are conflicting information about the optimal serum levels of $25(\mathrm{OH}) \mathrm{D}$. Vitamin D deficiency is defined by total $25(\mathrm{OH}) \mathrm{D}$ levels of $<20 \mathrm{ng} / \mathrm{mL}$ while vitamin D insufficiency may be defined as a level of 20 to $31 \mathrm{ng} / \mathrm{mL}$ and levels of $\geq 32 \mathrm{ng} / \mathrm{mL}$ demonstrates sufficient levels (Kennel, Drake, Hurley, 2010; Bogunovic, Kim, Beamer, Nguyen, Lane, 2010). From the point of view for athletes' health, recent studies showed that vitamin $\mathrm{D}$ has a significant role on skeletal health, immune system and optimal sports performance (Halliday, Peterson, Thomas, Kleppinger, Hollis, Larson-Meyer, 2011; Earthman, Beckman, Masodkar, Sibley, 2012). The deficiency of vitamin D may lead an increased risk for stress fractures, infections and muscle sensitivity (Lappe, Cullen, Haynatzki, Recker, Ahlf, Thompson, 2008). The prevalence of vitamin D insufficiency and deficiency in athletes is about $55 \%$ with a higher incidence in winter/spring seasons and players of indoor sports (Farrokhyar, 2015). In a recent National Collegiate Athletic Association (NCAA) study, the prevalence is \%33.6, although the study was carried out in the summer months (Villacis, Yi, Jahn, Kephart, Charlton, 2014). A recent meta-analysis found that $56 \%$ of athletes had vitamin D inadequacy (Farrokhyar et al., 2015). Also, a sizeable 
number of indoor sports athletes do not meet their nutritional needs for vitamin $\mathrm{D}$ in addition to their inadequate endogenous synthesis (Larson-Meyer, Willis, Kentz, 2010). Vitamin D deficiency may be multifactorial, such as reduced synthesis, absorption and genetic predisposition of impaired vitamin D metabolism (Holick, 2007). Decreased cutaneous synthesis of vitamin D is the main reason of deficiency in athletic population which is the most important factor for indoor athletes (Close et al., 2013). Although dietary intake of vitamin D makes up a small quantity of total vitamin D needs, sources of dietary vitamin D including fish, dairy (especially enriched sources) and eggs. The main source of vitamin D is provided by UVB light, and its formation may be affected by age, season, location, clothing style, high-impact creams applied to the skin and skin pigmentation (Angeline, Gee, Shindle, Warren, Rodeo, 2013).

Another issue that has been discussed recently is the association between vitamin D and body composition. Excess body fat or being overweight is also increased risk for those who has low vitamin D levels in non-athletes (Drincic, Armas, Van Diest, Heaney, 2012). Although the exact mechanism remains unclear, the majority of the recent evidence notifies that obesity and low vitamin D status affects each other (Gallagher, Yalamanchili, Smith, 2013). Higher serum vitamin D concentrations have also been related with better muscle strength and performance in some (Scott, Blizzard, Fell, Ding, Winzenberg, Jones, 2010; Ward et al., 2009; Zhu, Austin, Devine, Bruce, Prince, 2010), but not all studies (Ceglia, Chiu, Harris, Araujo, 2011; Verreault, Semba, Volpato, Ferrucci, Fried, Guralnik, 2002). Several investigators have reported the inadequacy or insufficiency of vitamin D for athletes but only limited study is reported the association of exercise, cardiorespiratory fitness and vitamin D. Studies have shown vitamin D deficiency and its relation with exercise types (Ceglia, Chiu, Harris, Araujo, 2011; Verreault, Semba, Volpato, Ferrucci, Fried, Guralnik, 2002). Maximal oxygen consumption is one of the measuring type of anaerobic capacity levels; Friedlander et al. (Friedlander, Genant, Sadowsky, Byl, Gluer, 1995) also found a positive relation between bone mineral density, serum PTH and $\mathrm{VO}_{2}$ max levels in women (aged 20-35 years). Although many researches have been studied on the relationship of exercise and bone density, there is no exact information about the association with cardiorespiratory fitness $\left(\mathrm{VO}_{2} \mathrm{max}\right)$.

In summary, low serum vitamin $25(\mathrm{OH}) \mathrm{D}$ levels may be affective on the body composition. In other aspect, we know that, as mentioned above, serum vitamin $25(\mathrm{OH}) \mathrm{D}$ is related to serum calcium and PTH levels in terms of bone and skeletal health. Although the 
mechanism of serum vitamin D interactions with cardiorespiratory fitness is unclear, the association between exercise and bone mineral density and/or mass is well known. There is direct relationship between serum vitamin $25(\mathrm{OH}) \mathrm{D}$ levels and athletic performance, as well as sedentary/active individuals. Athletes need rapid growth of bone and muscle mass and relation to these needs, they have a high demand of vitamin D. Many factors that can cause lack of vitamin D in athletes. Beyond these, serum vitamin $25(\mathrm{OH}) \mathrm{D}$ level is important for maintaining bone health and homeostasis. We aim to show the differences between the branches (by separating indoor/outdoor) and for all participants for these parameters. It is known that vitamin $\mathrm{D}$ has an effect on athlete health, body composition and many other factors. From this point, this study aims to show the relation between serum vitamin D and calcium levels with the $\max \mathrm{VO}_{2}$ (as an aerobic capacity marker) and body composition in indoor/outdoor athletes, competing in different fields. Original side of our work is that, there was no enough study that shows the relation with vitamin D and aerobic capacity markers according to the neither branches nor indoor/outdoor sports.

\section{Methods}

Males aged 17 to 37 were recruited as volunteer participants. Athletes were selected from the summer camp which is located in Bolu, Turkey. A voluntary consent form was obtained from all the participants. Volunteers were healthy athletes who had white skin and were regularly practicing during the summer camping season. Subjects who took calcium or vitamin D supplements, have diabetes mellitus, cardiovascular diseases, neurological disorders, and other serious medical conditions were not included. Medical histories and other health parameters were questioned to determine the acute conditions that would affect cardiorespiratory fitness. The individuals thought to be unhealthy for study were removed. This study was conducted from June 2016 to August 2016 to reduce seasonal variations.

\section{Assessments}

Body weight and body fat percentage of the subjects were determined using a portable TANITA (BC-418 Body Analysis Monitoring Model) that is sensitive to 0,1 kg. Subject height was measured with a standard stadiometer. All the measurements were conducted before testing with each subject wearing a single T-shirt and underwear without sneakers (Baysal, Aksoy, Besler, Bozkurt, Keçecioğlu, 2008) . Body mass index (BMI) was calculated as a weight $(\mathrm{kg})$ divided by height squared $\left(\mathrm{m}^{2}\right)$. Percent of body fat, fat-free mass and basal metabolic rate (BMR) were obtained from TANITA measurements. Maximal $\mathrm{VO}_{2}$ was 
measured with maximal-graded treadmill test. American College of Sports Medicine (ACSM, 2000) $\mathrm{VO}_{2}$ max classification is used for normative data for male subjects. $\mathrm{VO}_{2}$ max levels were determined as very poor for who has <35.0 (13-19 years); <33.0 (20-29 years); <31.5 (30-39 years). Poor are defined as 35.0-38.3 (13-19 years); 33.0-36.4 (20-29 years); 31.5-35.4 (30-39 years). Superior defined as >55.9 (13-19 years); >52.4 (20-29 years) and >49.4 (30-39 years). A single blood sample $(10 \mathrm{ml})$ was obtained via venipuncture by a registered nurse. Participants' blood samples were drawn into standard tubes with no additives, kept to clot for 30-60 min at room temperature, and centrifuged at $3500 \mathrm{rpm}$ for $15 \mathrm{~min}$. Pipetted serum samples were stored at $-20^{\circ} \mathrm{C}$ until analysis. The $25(\mathrm{OH}) \mathrm{D}$ concentration were measured via Diasorin 25(OH)D RIA and PTH by intact PTH IRMA. Vitamin D deficiency is defined as a total $25(\mathrm{OH}) \mathrm{D}$ levels of $<20 \mathrm{ng} / \mathrm{mL}$. Vitamin D insufficiency is defined as a level of 20 to 31 $\mathrm{ng} / \mathrm{mL}$, and levels of $\geq 32 \mathrm{ng} / \mathrm{mL}$ demonstrates sufficient levels (Bischoff-Ferrari H.A., Giovannucci E., Willet W.C., Dietrich T., Dawson-Hughes B., 2006). The intreassay coefficient for both analysis is less than $10 \%$. The samples were analyzed at Gerede State Hospital Biochemistry Laboratory (Bolu, Turkey) for serum 25(OH)D. Blood samples were also determined for serum calcium levels by using a Technicon Autoanalyzer II.

\section{Statistical Analysis}

Statistical analyses were performed using the IBM SPSS Statistics Version 23.0 (SPSS Inc., Chicago, IL). Descriptive data are presented as an arithmetic means $\pm S D$ (SD). Spearman correlation coefficients were used to determine the association of $\mathrm{VO}_{2}$ max and body fat percent with bone markers. A p value of less than 0.05 was considered statistically significant.

\section{Results}

This study was conducted with a total of 51 male athletes including 14 volleyball, 12 basketball and 25 football players. Mean (SD) baseline measurements are shown in Table 1. The mean age was $26.3 \pm 5.21$ years. The mean $\mathrm{VO}_{2}$ max level of the athletes was $40.8 \pm 8.72$ $\mathrm{mL} / \mathrm{kg} / \mathrm{min}$; mean vitamin $\mathrm{D}$ level was $36.6 \pm 22.77 \mathrm{ng} / \mathrm{mL}$ and mean total calcium level was $8.9 \pm 1.38 \mathrm{ng} / \mathrm{dL}$. When branches categorized as indoor (volleyball and basketball) and outdoor (football) sports; we found that individuals in indoor sports were significantly higher fat mass $(\mathrm{p}=0.019)$ and fat free mass $(\mathrm{p}=0.000)$. On the contrary, $\mathrm{VO}_{2} \max (\mathrm{p}=0.001)$ and serum $25(\mathrm{OH}) \mathrm{D}(\mathrm{p}=0.000)$ levels were significantly lower in the indoor group. Serum total calcium levels were not different between branches. 
Table 1: Mean Characteristics of participants $(n=51)$

\begin{tabular}{lllll}
\hline Characteristic & $\begin{array}{l}\text { Indoor sports } \\
\text { Mean (SD) }\end{array}$ & $\begin{array}{l}\text { Outdoor sports } \\
\text { Mean (SD) }\end{array}$ & $\begin{array}{l}\text { Total } \\
\text { Mean (SD) }\end{array}$ & p-value \\
\hline Age (years) & $25.9 \pm 5.8$ & $26.8 \pm 4.4$ & $26.3 \pm 5.2$ & 0.450 \\
Fat \% & $11.7 \pm 3.9$ & $10.8 \pm 4.0$ & $11.3 \pm 3.9$ & 0.451 \\
Fat mass (kg) & $11.2 \pm 4.6$ & $8.5 \pm 3.4$ & $9.9 \pm 4.2$ & $\mathbf{0 . 0 1 9 *}$ \\
Fat free mass (kg) & $82.1 \pm 8.6$ & $68.6 \pm 6.0$ & $75.5 \pm 10.0$ & $\mathbf{0 . 0 0 0 *}$ \\
VO2 max (mL/kg/min) & $36.8 \pm 7.2$ & $44.9 \pm 8.3$ & $40.8 \pm 8.7$ & $\mathbf{0 . 0 0 1 *}$ \\
Serum 25(OH) D (ng/mL) & $25.0 \pm 18.5$ & $48.5 \pm 20.7$ & $36.6 \pm 22.7$ & $\mathbf{0 . 0 0 0 *}$ \\
Serum total calcium & $9.0 \pm 1.2$ & $8.8 \pm 1.5$ & $8.9 \pm 1.3$ & 0.365 \\
(ng/dL) & & & & \\
\hline${ }^{*}<0.005$, Mann Whitney U test was performed. Abbreviations: SD, Standard Deviation; 25(OH)D, 25-hydroxyvitamin D \\
$\mathrm{VO}_{2}$ max, maximal oxygen consumption
\end{tabular}

Categorized version of some variables of participants are given in the Table 2. Thirteen subjects (25.5\%) were categorized as having deficient, with a serum vitamin $25(\mathrm{OH}) \mathrm{D}$ level of less than $<20 \mathrm{mg} / \mathrm{dL}$. For all population, only twenty six subjects $(51.0 \%)$ were categorized as sufficient. When evaluated according to indoor and outdoor sports, there is found statistically difference; while twelve indoor sports athlete had serum vitamin $25(\mathrm{OH}) \mathrm{D}$ deficiency; only one subject from outdoor sports had serum vitamin $25(\mathrm{OH}) \mathrm{D}$ deficiency $(\mathrm{p}<0.05)$. Twenty subjects $(80.0 \%)$ of outdoor sports had sufficient serum vitamin $25(\mathrm{OH}) \mathrm{D}$, on the other hand 6 subject $(23.1 \%)$ of indoor sports had sufficient serum vitamin 25(OH)D levels.

When athletes evaluated in terms of $\max \mathrm{VO}_{2}$ levels, for all population, only 3 subjects $(5.9 \%)$ had superior level. For athletes, there was significant difference for indoor and outdoor sports; while 11 subjects $(44.0 \%)$ had was at levels of excellent (for outdoor sports), 3 subjects $(11.5 \%$ ) had levels of excellent (for indoor sports) ( $\mathrm{p}<0.05$ ). For total population very poor levels were found $26.9 \%$ of indoor sports; $12.0 \%$ for outdoor sports athletes $(\mathrm{p}<0.05)$ (Table 2).

When we evaluated the subjects according to the BMI classification, there was no subject that has under 18.5 besides over 30. Forty-one subjects (80.4\%) had BMI between 18.5 to 24.9 ; besides ten subjects $(19.6 \%)$ had BMI between 25.0 to 29.9 ; there was no statistically significant difference between groups $(\mathrm{p}>0.05)$. 
Table 2: Categorized Version of Some Variables of participants

\begin{tabular}{|c|c|c|c|}
\hline Characteristics & Indoor sports & Outdoor sports & Total \\
\hline Vitamin D levels & $\mathrm{N}(\%)$ & $\mathrm{N}(\%)$ & $\mathrm{N}(\%)$ \\
\hline Deficient $(<20 \mathrm{mg} / \mathrm{dL})$ & $12(46.2)$ & $1(4.0)$ & $13(25.5)$ \\
\hline Insufficient $(20-31 \mathrm{ng} / \mathrm{dL})$ & $8(30.8)$ & $4(16.0)$ & $12(23.5)$ \\
\hline Sufficient $(>32 \mathrm{ng} / \mathrm{dL})$ & $6(23.1)$ & $20(80.0)$ & $26(51.0)$ \\
\hline Total & $26(100.0)$ & $25(100.0)$ & $51(100.0)$ \\
\hline \multicolumn{4}{|l|}{$\mathrm{VO}_{2}$ max levels } \\
\hline Very poor & 7 (26.9) & $3(12.0)$ & $10(19.6)$ \\
\hline Poor & $8(30.8)$ & $1(4.0)$ & $9(17.6)$ \\
\hline Fair & $6(23.1)$ & $3(12.0)$ & $9(17.6)$ \\
\hline Good & $1(3.8)$ & $5(20.0)$ & $6(11.8)$ \\
\hline Excellent & $3(11.5)$ & $11(44.0)$ & $14(27.5)$ \\
\hline Superior & $1(3.8)$ & $2(8.0)$ & $3(5.9)$ \\
\hline Total & $26(100)$ & $25(100)$ & $51(100.0)$ \\
\hline \multicolumn{4}{|l|}{ BMI } \\
\hline$<18.5$ & None & None & None \\
\hline $18.5-24.9$ & $19(73.1)$ & $22(88.0)$ & $41(80.4)$ \\
\hline $25.0-29.9$ & $7(26.9)$ & $3(12.0)$ & $10(19.6)$ \\
\hline$>30.0$ & None & None & None \\
\hline Total & $26(100.0)$ & $25(100.0)$ & $51(100.0)$ \\
\hline
\end{tabular}

Table 3 presents the differences of age, body composition, $\mathrm{Max} \mathrm{VO}_{2}$ levels, and some bone marker measurements in terms of branches. $\mathrm{VO}_{2} \max (\mathrm{p}=0.004)$ and vitamin $\mathrm{D}$ levels $(\mathrm{p}=0.000)$ of football players were significantly higher while BMR $(\mathrm{p}=0.000)$ and fat free mass $(p=0.000)$ were statistically lower from volleyball and basketball players. Total calcium levels did not differ between groups. Football players had significantly higher $\mathrm{VO}_{2} \max$ $(\mathrm{p}=0.009)$ and vitamin $\mathrm{D}(\mathrm{p}=0.000)$ levels than volleyball players. Similarly, their $\mathrm{VO}_{2} \max$ $(\mathrm{p}=0.004)$ and vitamin $\mathrm{D}(\mathrm{p}=0.003)$ levels were statistically higher than basketball players. There were no significantly difference between basketball and volleyball players for all parameters. When the data evaluated according to branches, BMR $(\mathrm{p}=0.000)$, fat free mass $(\mathrm{p}=0.000), \mathrm{VO}_{2} \max (\mathrm{p}=0.004)$ and serum $25(\mathrm{OH}) \mathrm{D}(\mathrm{p}=0.000)$ levels were significantly different between groups. BMR and fat free mass of football players were lower while $\mathrm{VO}_{2}$ max and serum $25(\mathrm{OH})$ D levels were higher than volleyball and basketball players $(p<0.005)$. Only fat mass of football players were significantly lower than basketball players. 
Table 3: Comparison of parameters between branches

\begin{tabular}{|c|c|c|c|c|c|}
\hline & Volleyball & Football & Basketball & Total & P-value \\
\hline Age (years) & $25.4 \pm 6.4$ & $26.8 \pm 4.4$ & $26.3 \pm 5.3$ & $26.3 \pm 5.2$ & 0.687 \\
\hline BMI $\left(\mathbf{k g} / \mathbf{m}^{2}\right)$ & $24.1 \pm 2.0$ & $23.44 \pm 1.4$ & $23.8 \pm 2.0$ & $23.7 \pm 1.7$ & 0.465 \\
\hline BMR (kcal) & $2433 \pm 254.9^{\mathrm{a}}$ & $2004 \pm 181.7^{b}$ & $2438 \pm 325.6^{\mathrm{a}}$ & $2224 \pm 321.5$ & $0.000 *$ \\
\hline Fat $\%$ & $11.2 \pm 4.0$ & $10.8 \pm 4.0$ & $12.3 \pm 3.8$ & $11.3 \pm 3.9$ & 0.635 \\
\hline Fat mass (kg) & $10.6 \pm 4.4^{\mathrm{ab}}$ & $8.48 \pm 3.4^{b}$ & $11.9 \pm 4.9^{\mathrm{a}}$ & $9.9 \pm 4.2$ & 0.057 \\
\hline Fat free mass $(\mathbf{k g})$ & $82.0 \pm 7.9^{\mathrm{a}}$ & $68.6 \pm 6.0^{\mathrm{b}}$ & $82.1 \pm 9.7^{\mathrm{a}}$ & $75.5 \pm 10.0$ & $0.000 *$ \\
\hline $\begin{array}{l}\mathrm{VO}_{2} \max \\
(\mathrm{mL} / \mathrm{kg} / \mathrm{min})\end{array}$ & $37.5 \pm 7.8^{\mathrm{a}}$ & $44.9 \pm 8.3^{b}$ & $36.0 \pm 6.7^{\mathrm{a}}$ & $40.8 \pm 8.7$ & $0.004 *$ \\
\hline $\begin{array}{l}\text { Serum } 25(O H) D \\
(\mathrm{ng} / \mathrm{mL})\end{array}$ & $23.3 \pm 19.7^{\mathrm{a}}$ & $48.5 \pm 20.7^{b}$ & $27.1 \pm 17.5^{\mathrm{a}}$ & $36.6 \pm 22.7$ & $0.000^{*}$ \\
\hline $\begin{array}{l}\text { Serum total } \mathrm{Ca}^{+2} \\
(\mathrm{ng} / \mathrm{dL})\end{array}$ & $9.12 \pm 1.4$ & $8.8 \pm 1.5$ & $8.9 \pm 0.9$ & $8.9 \pm 1.3$ & 0.638 \\
\hline
\end{tabular}

* $p<0.005$, Kruskal wallis test was performed. Mann Whitney U test was performed to compare groups.

Abbreviations: BMI, Body mass index, BMR, Basal metabolic rate

Table 4 presents the Spearman correlation coefficients between participants' cardiorespiratory fitness, some anthropometric measurements and vitamin D levels. Vitamin D level was inversely associated with body weight $(\mathrm{p}=0.003)$, fat free mass $(\mathrm{p}=0.000)$ and $\operatorname{BMR}(\mathrm{p}=0.000) . \mathrm{VO}_{2}$ max data was inversely associated with fat free mass $(\mathrm{p}=0.009), \mathrm{BMR}$ $(\mathrm{p}=0.012)$ and body weight $(\mathrm{p}=0.012)$. There was no significant correlation of total calcium levels with any of the other parameters.

Table 4: Correlations between some parameters of bone markers and anthropometric measurements

\begin{tabular}{|c|c|c|c|c|c|c|c|c|c|c|}
\hline \multirow[t]{2}{*}{ Characteristics } & \multicolumn{2}{|c|}{ Total Ca } & \multicolumn{2}{|c|}{$\begin{array}{c}\mathrm{VO}_{2} \max \\
(\mathrm{mL} / \mathrm{kg} / \mathrm{min})\end{array}$} & \multicolumn{2}{|c|}{$\begin{array}{l}\text { Body weight } \\
\text { (kg) }\end{array}$} & \multicolumn{2}{|c|}{ BMR } & \multicolumn{2}{|c|}{ Fat free mass } \\
\hline & spearman $r$ & $\mathrm{P}$ value & spearman $\mathrm{r}$ & P value & spearman & $\mathrm{P}$ value & spearman $\mathrm{r}$ & $\mathrm{P}$ value & spearman $\mathrm{r}$ & $P$ value \\
\hline Serum 25(OH)D & 0.12 & 0.391 & 0.09 & 0.535 & -0.41 & $0.003 *$ & -0.50 & 0.000 & -0.51 & $0.000 *$ \\
\hline$\underset{\mathrm{Ca}^{+2}}{\text { Serum total }}$ & -- & -- & -0.15 & 0.289 & 0.14 & 0.318 & 0.10 & 0.467 & 0.15 & 0.301 \\
\hline $\mathrm{VO}_{2} \max$ & -- & -- & -- & -- & -0.35 & $0.012 *$ & -0.35 & 0.012* & -0.36 & 0.009* \\
\hline
\end{tabular}

${ }^{*} p<0.005$, Spearman correlation analysis was performed.

\section{Discussion}

The active role of vitamin $\mathrm{D}$ in musculoskeletal health has reported before (Wahl et al., 2012). The prevalence of vitamin D deficiency and insuffiency is a global health problem (Quraishi, Camargo, Manson, 2016) both in general population (Quraishi, Camargo, Manson, 2016; Cashman et al., 2016) and athletes (Farrokhyar et al., 2015; Fishman, Lomabrdo, Kharrazi, 2016). 
Studies have shown that vitamin D deficiency has significant effects on general health parameters of adolescents, as well as the athletic performance and related common wounds. Training in indoors may increase vitamin D deficiency and insufficiency in athletes. For trainers in outdoors; being at high latitudes (>32 degrees north or south), training very early or late in the day when the sunlight exposure is minimum (Larson-Meyer, Willis, Kentz, 2010; Hamilton, Grantham, Racinais, Chalabi, 2010) or with limited skin exposure to sunlight may be other risk factors for vitamin D insufficiency and deficiency. The purpose of the study was to determine; whether cardiorespiratory fitness and anthropometric measurements were associated with bone marker measurements (Vitamin D, calcium, PTH). We also evaluated potential differences between branches based on outdoor/indoor sports.

The findings from this study, 25 athletes trained outdoors (football) and 26 athletes were indoors sports (volleyball 14; basketball 12). The mean age of the participants was $26.3 \pm 5.21$ years; the mean professional practice age was $8.02 \pm 3.13$ years. We found that there is significant difference between indoor and outdoor sports for BMR ( $\mathrm{p}=.000)$, fat mass $(\mathrm{p}=.019)$, fat free mass $(\mathrm{p}=.000), \mathrm{VO}_{2} \max (\mathrm{p}=.001)$ and vitamin $25(\mathrm{OH}) \mathrm{D}$ levels $(\mathrm{p}=.000)$. This difference can be explained by the levels of serum vitamin D levels. A recent study reported that the athletes with high vitamin D levels have low body fat and high fat free mass (He et al., 2013); while outdoor sports have higher serum vitamin D levels (Halliday, Peterson, Thomas, Kleppinger, Hollis, Larson-Meyer, 2011). Our findings are in contrast with the majority of the previous studies (Kremer, Campbell, Reinhardt, Gilsanz, 2009; Harris, Dawson-Hughes, 2007) which reported that sufficiency of vitamin D is correlated with lower body fat mass. Our study suggests that athletes engaged in outdoor sports had lower fat mass, fat free mass; higher $\mathrm{VO}_{2} \max$ and serum vitamin $25(\mathrm{OH}) \mathrm{D}$. But fat free mass of indoor athletes' were also found to be low. This may due to the fact that the indoor athletes have visibly large body size and height. In our study, it was found that for outdoor sports, $\mathrm{VO}_{2} \max$ $(\mathrm{p}=.001)$ and serum $25(\mathrm{OH}) \mathrm{D}$ levels $(\mathrm{p}=.000)$ were statistically different.

In our study, we evaluated athletes' aerobic fitness by max $\mathrm{VO}_{2}$ levels. Improved $\mathrm{VO}_{2}$ max levels may be related to increased $25(\mathrm{OH})$ D activity on cardiac myocytes (Close et al., 2013; Constantini, Arieli, Chodick, Dubnov-Raz, 2010). Our findings showed a large range in serum $25(\mathrm{OH}) \mathrm{D}$ levels. When we examine the parameters in terms of branches, it was found that $\mathrm{VO}_{2} \max (\mathrm{p}=0.004)$ and vitamin $\mathrm{D}$ levels $(\mathrm{p}=0.000)$ of football players were significantly higher while BMR $(\mathrm{p}=0.000)$ and fat free mass $(\mathrm{p}=0.000)$ were statistically lower 
from volleyball and basketball players. Total calcium levels did not differ between groups; there was no relationship between subjects' $\max \mathrm{VO}_{2}$ levels and serum calcium levels.

Despite overall good vitamin D status in the half majority (51.0\%), about fifty percent of the population had deficient $(25.5 \%)$ or insufficient $(23.5 \%)$ level. About $46.2 \%$ of indoor sports athletes had deficient Vitamin D levels and about $30.8 \%$ of them had insufficient levels of vitamin D. This result is parallel with other studies (He et al., 2013; Halliday, Peterson, Thomas, Kleppinger, Hollis, Larson-Meyer, 2011) done in recent years. Serum vitamin D and body fat free mass were negatively correlated; while there was no significant correlation with body fat mass, supported the hypothesis of fat sequestration (Wortsman, Matsuoka, Chen, Lu, Holick, 2000). Our findings are in contrast with the majority of previous studies which report that while serum vitamin D increases, body fat mass decreases (Harris, Dawson-Hughes, 2007; Kull, Kallikorm, Lember, 2009). The current study also sought to determine whether body size and/or adiposity are also predictors of vitamin D status in athletes as it is in general population (Heller, Thomas, Hollis, Larson-Meyer, 2015; Drincic, Armas, Van Diest, Heaney, 2012). To our knowledge, few studies have showed the relation between body size or composition and vitamin D status in athletic populations, and few were not able to evaluate populations with a wide enough range in adiposity (Lewis, Redzic, Thomas, 2013). This study offers the advantage of including football players which tend to be heavier than other sport athletes, which varying adiposity and fat free mass. This may be because of $25(\mathrm{OH}) \mathrm{D}$ storage in body fat as Wortsman et al suggested (Wortsman, Matsuoka, Chen, Lu, Holick, 2000).

There are some limitations of our study such as its small sample size, involving only 51 participants. Evaluating only serum $25(\mathrm{OH}) \mathrm{D}$ and serum total calcium levels may also be other limitation. Other commonly used markers as serum PTH and phosphorus levels or bone mass density, were not determined in the present study. Also, we didn't examine participants' diet history and the amount of dietary vitamin $\mathrm{D}$ and calcium intake. There is also one reason that we can represent as a limitation that, athletes had just attended to the summer camps. So we know that they have an uncontrolled 2-month process, they have the right to eat and drink everything they wish. This situation may affect the athletes' body composition and overall performance indicators. It may be more accurate to repeat the end of the camping season.

\section{Conclusions}

In this study, it was found that healthy young athletes (from 3 different branches), lower body weight and greater $\mathrm{VO}_{2}$ max, are associated with higher levels of serum $25(\mathrm{OH}) \mathrm{D}$ 
independent of serum total calcium levels. This study presents that, fat mass and fat free mass were significantly higher for indoor sports athletes. On the contrary, $\mathrm{VO}_{2}$ max intake and serum vitamin $25(\mathrm{OH}) \mathrm{D}$ levels were significantly lower for indoor athletes. We know that serum vitamin $\mathrm{D}$ levels are affected at a moderate level in the diet. The sufficiency or insufficiency of vitamin D may be associated with genetic background of our Turkish athletes.

Further studies are needed for understanding the exact effects and metabolism of $25(\mathrm{OH}) \mathrm{D}$, body composition and $\max \mathrm{VO}_{2}$ levels. Daily vitamin $\mathrm{D}$ and calcium intake may influence the participants' general health issues. From this point, determining dietary intake of vitamin $\mathrm{D}$ influences health outcomes in athletes from different branches would also be a valuable perspective for further studies.

\section{Acknowledgments}

We would like to thank to, Ateş Şendil, PhD, for the data collection process and his assistance. 


\section{References}

American College of Sports Medicine. (2000). ACSM's guidelines for exercise testing and prescription $\left(6^{\text {th }}\right.$ ed $)$. Philadelphia: Lippincott Williams \& Wilkins.

Angeline, M.E., Gee, A.O., Shindle, M., Warren, R.F., Rodeo, S.A. (2013). The Effects of Vitamin D Deficiency in Athletes. American Journal of Sports Medicine: SAGE Journals; 41,2. DOI: $10.1177 / 0363546513475787$.

Bailey D.A., McKay, H.A., Mirwald, R.L., Crocker, P.R., Faulkner, R.A. (1999). A six-year longitudinal study of the relationship of physical activity to bone mineral accrual in growing children: the University of Saskatchewan bone mineral accrual study. Journal of Bone and Mineral Research; 14, 1672-1679.

Baysal A., Aksoy M., Besler H.T., Bozkurt N, Keçecioğlu S. (2008). Beden Ağırlığının Denetimi. Diyet El Kitabı (5. Baskı), Ankara: Hatiboğlu Yayınevi.

Bischoff-Ferrari H.A., Giovannucci E., Willet W.C., Dietrich T., Dawson-Hughes B. (2006). Estimation of optimal serum concentrations of 25-hydroxyvitamin D for multiple health outcomes. American Journal of Clinical Nutrition; 84, 18-28.

Bogunovic, L., Kim, A.D., Beamer, B.S., Nguyen, J., Lane, J.M. (2010). Hypovitaminosis D in patients scheduled to undergo orthopaedic surgery: a single-center analysis. Journal of Bone and Joint Surgery American Volume; 92, 2300-2304.

Cannell, J.J., Hollis, B.W., Sorenson, M.B., Taft, T.N., Anderson, J.J. (2009). Athletic performance and vitamin D. Medicine and Science in Sports and Exercise; 41, 11021110.

Cashman, K.D., Dowling, K.G., Skrabakova, Z., Gonzales-Gross, M., Valtuena J et al. (2016). Vitamin D deficiency in Europe: pendemic? American Journal of Clinical Nutrition; 103(4), 1033-1044.

Ceglia, L., Chiu, G.R., Harris, S.S., Araujo, A.B. (2011). Serum 25-hydroxyvitamin D concentration and physical function in adult men. Clinical Endocrinology (Oxf); 74(3), 370-376. PubMed: 21083597.

Close, G.L., Leckey, J., Patterson, M., Bradley, W., Owens, D.J., Fraser, W.D., Morton, J.P. (2013). The effects of vitamin D3 supplementation on serum total 25(OH)D concentration and physical performance: A randomised dose-response study. British Journal of Sports Medicine; 47(11), 692-696.

Constantini, N.W., Arieli, R., Chodick, G., Dubnov-Raz, G. (2010). High prevelance of vitamin D insufficiency in atheletes and dancers. Clinical Journal of Sport Medicine; 20(5), 368-371.

Drincic, A.T., Armas, L.A., Van Diest, E.E., Heaney, R.P. (2012). Volumetric dilution, rather than sequestration best explains the low vitamin D status of obesity. Obesity (Silver Spring, Md.); 20(7), 1444-1448. PubMed doi:10.1038/oby.2011.404

Earthman, C.P., Beckman, L.M., Masodkar, K., Sibley, S.D. (2012). The link between obesity and low circulating 25-hydroxyvitamin D concentrations: considerations and implications. International Journal of Obesity (Lond); 36(3), 387-396. PubMed doi:10.1038/ijo.2011.119.

Farrokhyar, F., Tabasinejad, R., Dao, D., Peterson, D., Ayeni, O.R., Hadioonzadeh, R., Bhandari, M. (2015). Prevalence of Vitamin D Inadequacy in Athletes: A Systematic Review and Meta-Analysis. Sports Medicine; 45, 365-378.

Fishman, M.P., Lomabrdo, S.J., Kharrazi, F.D. (2016). Vitamin D Deficiency Among Professional Basketball Players. Orthopaedic Journal of Sports Medicine; 4(7), 2325967116655742. Article first published online: July 6, 2016; Issue published: July 1, 2016 https://doi.org/10.1177/2325967116655742.

Friedlander, A.L., Genant, H.K., Sadowsky, S., Byl, N.N., Gluer, C.C. (1995). A two-year program of aerobics and weight training enhances bone mineral density of young women. Journal of Bone and Mineral Research; 10, 574-585.

Gallagher, J.C., Yalamanchili, V., Smith, L.M. (2013). The effect of vitamin D supplementation on serum 25(OH)D in thin and obese women. Journal of Steroid Biochemistry and Molecular Biology; 136, 195-200. PubMed doi:10.1016/j.jsbmb.2012.12.003. 
Gutierrez, O.M., Farwell, W.R., Kermah, D., Taylor, E.N. (2011). Racial differences in the relationship between vitamin $\mathrm{D}$, bone mineral density, and parathyroid hormone in the National Health and Nutrition Examination Survey. Osteoporosis International; 22(6), $1745-1753$.

Halliday, T.M., Peterson, N.J., Thomas, J.J., Kleppinger, K., Hollis, B.W., Larson-Meyer, D.E. (2011). Vitamin D status relative to diet, lifestyle, injury, and illness in college athletes. Medicine and Science in Sports and Exercise; 43(2), 335-343. PubMed doi:10.1249/MSS.0b013e3181eb9d4d

Hamilton, B., Grantham, J., Racinais, S., Chalabi, H. (2010). Vitamin D deficiency is endemic in Middle Eastern sportsmen. Public Health Nutrition; 13, 1528-1534.

Harris, S.S., Dawson-Hughes, B. (2007). Reduced sun exposure does not explain the inverse association of 25-hydroxyvitamin D with percent body fat in older adults. Journal of Clinical Endocrinology and Metabolism; 92, 3155-3157.

He, C.S., Handzlik, M., Muhamad, A., Preston, H., Richardson, A, Gleeson M. (2013). Influence of vitamin $\mathrm{D}$ status on respiratory infection incidence and immune function during 4 months of winter training in endurance sport athletes. Exercise Immunology Review; 19, 86-101.

Heller, J.E., Thomas, J.J., Hollis, B.W., Larson-Meyer D.E. (2015). Relation Between Vitamin D Status and Body Composition in Collegiate Athletes. International Journal of Sport Nutrition and Exercise Metabolism; 25, 128-135.

Holick MF. (2007). Vitamin D deficiency. New England Journal Medicine; 357(3), 266-281.

Holick, M.F., Binkley, N.C., Bischoff-Ferrari, H.A., Gordon, C.M, Hanley, D.A., Murad, M.H, Weaver, C.M. (2012). Guidelines for preventing and treating vitamin D deficiency and insufficiency revisited. Journal of Clinical Endocrinology Metabolism; 97, 1153-1158.

Kremer, R., Campbell, P.P., Reinhardt, T., Gilsanz V. (2009). Vitamin D Status and Its Relation to Body Fat, Final Height, and Peak Bone Mass in Young Women. Journal of Clinical Endocrinolgy and Metabolism; 94(1), 67-73.

Kull, N., Kallikorm, R., Lember, M. (2009). Body mass index determines sunbathing habits: implications on vitamin D levels. Internal Medicine Journal; 39, 256-258.

Lappe, J., Cullen, D., Haynatzki, G., Recker, R., Ahlf, R., Thompson, K. (2008). Calcium and vitamin d supplementation decreases incidence of stress fractures in female navy recruits. Journal of Bone and Mineral Research; 23(5), 741-749. PubMed doi:10.1359/jbmr.080102.

Larson-Meyer, D.E, Willis, K.S. (2010). Vitamin D and Athletes. Sports Medicine Reports:9(4), 220-226.

Lewis, R.M., Redzic, M., Thomas, D.T. (2013). The effects of season-long vitamin d supplementation on collegiate swimmers and divers. International Journal of Sport Nutrition and Exercise Metabolism; 23(5), 431-440.

Nordstrom, A., Karlsson, C., Nyquist, F., Olsson, T., Nordstrom, P., Karlsson, M. (2005). Bone loss and fracture risk after reduced physical activity. Journal of Bone and Mineral Research; 20, 202-207.

Quraishi, S.A., Camargo, C.A., Manson, J.E. (2016). Low vitamin D status in Europe: moving from evidence to sound public health policies. American Journal of Clinical Nutrition; 103, 957-958; First published online March 16, 2016. doi:10.3945/ajcn.116.132274.

Scott, D., Blizzard, L., Fell, J., Ding, C., Winzenberg, T., Jones, G. A. (2010). Prospective study of the associations between 25-hydroxy-vitamin D, sarcopenia progression and physical activity in older adults. Clinical Endocrinology (Oxf); 73(5), 581-587. PubMed: 20681994.

Sohl, E., de Jongh, R.T., Heymans M.W., van Schoor, N.M., Lips, P. (2015). Thresholds for Serum 25(OH)D Concentrations with Respect to Different Outcomes. Journal of Clinical Endocrinology \& Metabolism; 100(6), 2480 -2488.

Verreault, R., Semba, R.D., Volpato, S., Ferrucci, L., Fried, L.P., Guralnik, J.M. (2002). Low serum vitamin d does not predict new disability or loss of muscle strength in older women. Journal of American Geriatrics Society; 50(5), 912-917. PubMed: 12028180. 
Villacis, D., Yi, A., Jahn, R., Kephart, C.J., Charlton, T. (2014). Prevalence of Abnormal Vitamin D Levels Among Division I NCAA Athletes. Sports Health; 6(4), 340-347.

Wahl, D.A., Cooper, C., Ebeling, P.R., Eggersdorfer, M., Hilger, J, Hoffmann, K., Josse, R, Kanis, J.A., Mithal, A., Stenmark, J., Stöcklin, E., Dawson-Hughes, B. (2012). A global representation of vitamin D status in healthy populations. Archive of Osteoporosis; 7(1-2), $155-72$.

Ward, K.A., Das, G., Berry, J.L., Roberts, S.A., Rawer, R., Adams, J.E., Mughal, Z. (2009). Vitamin D status and muscle function in post-menarchal adolescent girls. Journal of Clinical Endocrinology \& Metabolism; 94(2), 559-63. PubMed: 19033372.

Whiting, S.J., Vatanparast, H., Baxter-Jones, A., Faulkner, R.A., Mirwald, R., Bailey, D.A. (2004). Factors that affect bone mineral accrual in the adolescent growth spurt. Journal of Nutrition; 134, 696-700.

Wortsman, J., Matsuoka, L.Y., Chen, T.C., Lu, Z., Holick, M.F. (2000). Decreased bioavailability of vitamin D in obesity. American Journal of Clinical Nutrition; 72(3), 690-693.

Zhu, K., Austin, N., Devine, A., Bruce, D., Prince, R.L. (2010). A randomized controlled trial of the effects of vitamin D on muscle strength and mobility in older women with vitamin D insufficiency. Journal of American Geriatrics Society; 58(11), 2063-2068. PubMed: 21054285 